\title{
Karakterisasi Genotipe Jagung Toleran Kekeringan Di Lahan Kering
}

\author{
Muh. Rifqy Aulya ${ }^{1}$, St. Subaedah ${ }^{2}$, Andi Takdir ${ }^{3}$ \\ ${ }^{1}$ Program Studi Agroteknologi Universitas Al Asyariah Mandar \\ ${ }^{2}$ Program Studi Agroteknologi Universitas Muslim Indonesia \\ ${ }^{3}$ Program Studi Agroteknologi Universitas Muslim Indonesia \\ Email :rifqy_aulya@yahoo.com
}

\begin{abstract}
Abstrak
Karakterisasi Genotipe Jagung Toleran Kekeringan di Lahan Kering.Penelitian ini bertujuan untuk mengetahui dan menganalisis keragaan morfologi beberapa genotipe jagung pada berbagai cekaman kekeringan di lahan kering.Rancangan percobaan yang digunakan adalah rancangan petak terbagi, yang terdiri dari 3 taraf yaitu tanpa cekaman, cekaman sedang, dan cekaman parah. Sebagai anak petak adalah jagung calon hibrida 8 genotipe yaitu G1, G2, G3,G4, G5, G6, G7, G8,dan penggunaan 2 varietas pembanding yaitu Bima 7 dan Gumarang. Setiap kombinasi perlakuan diulang sebanyak tiga kali sebagai kelompok sehingga diperoleh 90 unit percobaan.Hasil analisa statistik terhadap variabel pengamatan untuk komponen pertumbuhan tanaman menunjukkan bahwa perbandingan antara Genotpe dan varietas berbeda nyata terhadap 2 parameter pengamatan yaitu tinggi tanaman dan jumlah daun. Tinggi tanaman tertinggi terdapat pada perlakuan cekaman sedang pada genotipe G-8 $(251,57 \mathrm{~cm})$ yang berbeda nyata lebih tinggi daripada varietas Bima 7 dan Gumarang dan jumlah daun tertinggi terdapat pada perlakuan optimal pada genotipe G-6 dan G-7 (15,0 dan 14,0 helai) yang berbeda nyata dengan kedua varietas Bima 7 dan Gumarang.Sedangkan 2 genotipe untuk parameter Tinggi Tanaman, jumlah daun berbeda nyata dengan varietas bima 7 dan gumarang. Komponen produksi tanaman menunjukkan bahwa anatara genotipe dan varietas memberikan pengaruh nyata terhadap 6 parameter pengamatan yaitu, , Diameter tongkol, skoring penutup kelobot, bobot tongkol, panjang tongkol, bobot 1000 biji, dan hasil per hektar (ton/ha) sedangkan diameter tongkol tidak berbeda nyata dengan varietas bima 7 dan gumarang. Berdasarkan data komponen produksi tanaman yang menunjukkan pengaruh sangat nyata maka hal ini dapat diduga disebabkan oleh pemberian air sangat mempengaruhi proses produksi tanaman. Hal ini dapat terjadi karena pada saat proses fotosintesis, air sangat dibutuhkan untuk metabolisme sel, pembentukan bahan dan energi untuk masuk pada fase reproduksi pembentukan bunga dan pengisian bij sehinggga akan berpengaruh terhadap bobot tongkol dan hasil per hektar (ha/ton), Berdasarkan hasil penelitian, dapat disimpulkan bahwa: Genotipe G-1, G-3, G6, G-7 dan G-8 mempunyai penampilan tanaman yang tertinggi dan terpanjang baik pada kondisi optimal maupun tercekam kekeringan. Genotipe G-6 dan G-7 dan G-8 mempunyai bobot tongkol terberat,dan produksi tertinggi yaitu \pm 7 ton/ha pada kondisi optimal dan \pm 5 ton/ha pada kondisi tercekam kekeringan.
\end{abstract}

Keywords :Jagung; Genotipe; Karakterisasi; Kekeringan

\section{PENDAHULUAN}

Jagung merupakan salah satu tanaman serealia yang tumbuh hampir di seluruh dunia tergolong spesies dengan variabilitas genetik yang besar.Tanaman jagung dapat menghasilkan genotipe baru yang dapat beradaptasi terhadap berbagai karakteristik lingkungan. Di Indonesia, jagung merupakan bahan makanan pokok kedua setelah padi. Jagung pun digunakan sebagai bahan makanan ternak (pakan)dan bahan baku industri. Di lain pihak, produksi jagung saat ini masih belum mencukupi kebutuhan dalam negeri sehingga Pemerintah harus mengimpor setiap tahun dari luar negeri. (Kementrian Pertanian, 2012).

Perluasan areal tanaman jagung pada lahan kering merupakan alternatif solusi terhadap masalah ketahanan pangan nasional.Lahan kering selalu dikaitkan dengan lahan yang terdapat di wilayah kering (kekurangan air) yang tergantung pada air hujan sebagai sumber air. Kendala utama pengembangan pertanian pada kawasan lahan kering antara lain kadar air tanah tersedia rendah, akibatnya tanaman yang tumbuh pada kondisi ini dapat mengalami defisit air sehingga sulit memberikan hasil sesuai dengan potensi yang dimilikinya. Hal ini dapat terjadi karena defisit air selain berpengaruh secara langsung terhadap berbagai proses fisiologis dalam tanaman, juga mengurangi kemampuan tanaman dalam menyerap unsur hara. Kekeringan mempengaruhi respon fisiologis, biokimia dan molekuler yang mengatur pertumbuhan dan produktivitas tanaman.Produktivitas lahan kering cepat menurun karena lahan kering mudah terdegradasi.Di daerah iklim tropika seperti Indonesia dengan polaintensitas penyinaran matahari dan curah hujan yang tinggi dan 
hampir merata sepanjang tahun serta temperatur dan kelembaban udara yang tinggi mengakibatkan dekomposisi bahan organik dan pelepasan hara berlangsung cepat.Kondisi tersebut menyebabkan tanah menjadi reaktif atau peka dan mempunyai tingkat erosi serta pencucian (leaching) yang tinggi (Efendi $d k k$, 2009). Jagung merupakan tanaman serealia yang tumbuh di seluruh dunia, yang sensitif dengan kekeringan.Diperkirakan produksi jagung didunia menurun akibat cekaman kekeringan.Lahan kering merupakan salah satu agroekosistem yang mempunyai potensi besar untuk usaha pertanian tanaman pangan (Abdurachmandkk. 2008).

Pengembangan jagung pada areal baru akan banyak memanfaatkan lahan kering yang kurang subur (lahan masam). Untuk meningkatkan produksi jagung di lahan kering dapat dilakukan melalui perbaikan produktivitas dan adaptasi tanaman.Perbaikan adaptasi tanaman diperlukan pemahaman ilmu fisiologi tentang mekanisme yang mendasari peningkatan potensial hasil dan perbaikan adaptasi tanaman terhadap berbagai cekaman abiotik (Sopandie 2006 dalam Agustina $d k k$. 2010).

Evaluasi karakteristik genotipe merupakan salah satu langkah yang dilakukan pemulia tanaman untuk mendapatkan informasi mengenai genotipe-genotipe yang ada. Menurut Allard(1960), evaluasi berguna untuk mengetahui manfaat satu genotipe, genotipe yang perlu diseleksi lebih lanjut, dan genotipe-genotipe yang dapat dijadikan tetua dalam hibridasi selanjutnya. Van Der Have(1979) menyatakan bahwa evaluasi merupakan suatu langkah dalam pemuliaan tanaman untuk mengetahui perbedaan varietas serta menguji kestabilan suatu galur yang akan dilepas menjadi varietas, sehingga ketika varietas itu dilepas akan menunjukkan genotipe sesuai dengan spesifikasi yang diberikan oleh pemulia tanaman. Oleh karena itu diperlukan jagung varietas toleran kekeringan, dari uraian tersebutmaka perlu dilakukan penelitian berhubungan dengan karakterisasi genotipe jagung toleran kekeringan.

\section{Metode Penelitian}

Penelitian ini dilakukan dalam bentuk percobaan di lahan kering yang berlokasi di Kebun Percobaan Bajeng (Bajeng Experimental Station), Balai Penelitian Tanaman Serelia, Badan Penelitian dan Pengembangan Pertanian, Kementrian Pertanian Republik Indonesia, Kecamatan Bajeng, Kabupaten Gowa, Provinsi Sulawesi Selatan. Daerah tersebut terletak pada ketinggian $55 \mathrm{~m}$ diatas permukaan laut (dpl) dengan kemiringan lahan $<3 \%$, serta jenis tanah tergolong Inceptisols, dan tingkat kesuburan tanah rendah sampai sedang. Penelitian ini berlangsung dari bulan Juli sampai September 2016. Penelitian ini dilaksanakan dengan menggunakan metode rancangan petak terbagi (Split Plot Design)sebagai petak utama adalah perlakuan cekaman yang terdiri dari 3 taraf yaitu :C0 :tanpa cekaman (pemberian air dilakukan secara optimal yaitu sekali dalam 10 hari), C1 :cekaman sedang (pemberian air dihentikan pada saat tanaman berumur 35 sampai 65 hari setelah tanam)C2 :cekaman parah (pemberian air dihentikan setelah tanaman berumur 35 hari sampai panen). Sebagai anak petak adalah genotipegenotipe jagung calon hibrida yang terdiri dari 8 genotipe dan yaitu: G1 (ST201315), G2 (ST201328),G3 (ST201342), G4 (ST201364), G5 (ST201320), G6 (ST201359),G7 (ST201312),G8 (ST201309)dan penggunaan dua (2) varietas pembanding yaitu Bima 7 dan Gumarang. Populasi penyusun/material genetik populasi dasar berasal dari CIMMYT Mexico dari kelompok umur genjah dan toleran kekeringan.Setiap kombinasi perlakuan diulang sebanyak tiga kali sebagai kelompok sehingga diperoleh 90 unit percobaan.

\section{Hasil Dan Pembahasan}

\section{Tinggi Tanaman}

Tinggi tanaman dari delapan genotipe yang diuji dari perlakuan optimal, cekaman sedang dan cekaman parah berkisar antara 195,2-251,7 cm. Tinggi tanaman tertinggi terdapat pada perlakuan cekaman sedang pada genotipe G-8 $(251,57 \mathrm{~cm})$ yang berbeda nyata lebih tinggi daripada varietas Bima 7 dan Gumarang. Sedangkan tinggi tanaman terendah terdapat pada perlakuan optimal pada genotipe G-2 (195,20 cm).

\section{Jumlah Daun}

Jumlah daun dari delapan genotipe dari perlakuan optimal, cekaman sedang dan cekaman parah yang diuji berkisar antara 12,0-15,0 helai. Jumlah daun tertinggi terdapat pada perlakuan optimal dari genotipe G-6 dan G-7 (15,0 dan 14,0 helai) yang berbeda nyata dengan Bima 7 dan Gumarang sedangkan jumlah daun terendah terdapat pada perlakuan cekaman sedang pada genotipe G-5 (12,13 helai) dan cekaman parah genotipe G-5 (12,13 helai).

\section{Klorofil Daun}

Klorofil daun dari delapan genotipe yang diuji berkisar antara 36,82-54,70. Klorofil daun tertinggi terdapat padaperlakuan optimal pada genotipe G-6 $(54,70)$ yang tidak berbeda nyata dengan Bima 7 dan Gumarang.Klorofi Daun terendah terdapat pada perlakuan cekaman parah dengan genotipe G-4 $(36,82)$.

\section{Umur Panen}

Umur panen dari delapan genotipe yang diuji berkisar antara 85,00-89,00 hari. Umur panen tertinggi terdapat pada perlakuan cekaman sedang G-1 (89,00 hari) dan G4 (89,00 hari) dan cekaman parah pada genotipe G-1 $(89,00)$ dan G-4 $(89,00$ hari) berbeda nyata dengan Bima 7 dan Gumarang. Umur panen terendah terdapat pada perlakuan pada varietas Gumarang (83,00 hari). Ratarata umur panen dari delapan genotipe yang diuji secara genetik mempunyai umur panen yang lebih lama dibanding varietas Bima 7(87,00 hari)dan Gumarang $(85,00)$.Genotipe G-1, dan G-4 memiliki rata-rata umur panen paling lama(89,00 hari).

\section{Skoring Penutup Kelobot}

Pada skoring penutup kelobot menunjukkan perlakuan optimal pada Genotipe G-3 dan G-4 memilki tingkat penutupan kelobot terbaik $(1,0)$ dimana 
kelobotnya menutup rapat dengan baik. Sedangkan genotipe G-6pada perlakuan optimal, cekaman sedang dan cekaman parah masing-masing $(3,80),(3,13)$ dan $(3,53)$ memiliki tingkat penutup kelobot terendah yang tidak berbeda nyata dengan varietas Bima-7 dan Gumarang dimana kelobot menutup agak longgar diujung tongkol.

\section{Bobot Tongkol}

Bobot tongkol genotipe yang diuji berkisar antara 151,93-226,33gr. Perlakuan optimal pada Genotipe G-6 memiliki bobot tongkol tertinggi yaitu 226,33 g yang berbeda nyata dengan varietas Bima-7 dan Gumarang $(199,13 \mathrm{~g})$ dan $(178,47 \mathrm{~g})$ dan perlakuan cekaman sedang pada Genotipe G-7 memiliki bobot tongkol tertinggi yaitu 219,93 g yang berbeda nyata dengan varietas Bima7 dan Gumarang (191,60 g) dan (117,53 g).

\section{Panjang Tongkol}

Panjang tongkol genotipe yang diuji berkisar antara $15,69 \mathrm{~cm}-18,55 \mathrm{~cm}$. Genotipe G-7 dari perlakuan cekaman sedang memiliki panjang tongkol tertinggi yaitu $18,55 \mathrm{~cm}$ yang berbeda nyata dengan varietas Bima-7 (16,15 cm) dan Gumarang $(13,84 \mathrm{~cm})$.

\section{Diameter Tongkol}

Diameter tongkol genotipe yang diuji berkisar antara $3,46-4,55 \mathrm{~cm}$. Genotipe G-8 dari perlakuan optimal memiliki diameter tongkol tertinggi yaitu $(4,55 \mathrm{~cm})$ Diameter tongkol genotipe tersebut lebih besar dari pada varietas Bima-7 dan Gumarang sedangkan diameter tongkol terendah genotipe G-1 $(3,46 \mathrm{~cm})$ dari perlakuan cekaman parah.

\section{Kadar Air Biji}

Genotipe G-2 pada cekaman sedang memiliki kadar air biji terendah yaitu 20,16\%. Sedangkan genotipe G-4 pada perlakuan optimal memilki kadar air biji tertinggi $(25,10 \%)$ yang tidak berbeda nyata dengan varietas Bima$7(27,20 \%)$ dan Gumarang (25,50\%).

\section{Bobot Seribu Biji}

Bobot seribu biji genotipe yang diuji berkisar 207,33355,33 g. Genotipe G-7 pada cekaman sedang memiliki bobot 1000 biji tertinggi yaitu 355,33 g yang berbeda nyata dari Bima-7 (283,33 g) dan Gumarang (194,67 g) sedangkan Bobot 1000 biji terendah pada cekaman parah dari genotipe G-1 (207,33 g).

\section{Hasil Per Hektar (ton/ha)}

Hasil biji yang diuji dari delapan genotipe berkisar antara 4,11-7,48 ton/ha. Hasil biji tertinggi terdapat pada genotipe G-8 (7,48 ton/ha) yang berbeda nyata dengan gumarang sedangkan hasil biji terendah terdapat pada cekaman sedang pada Genotipe G-4 (4,11 ton/ha).

\section{Komponen Morfologi Tanaman}

Hasil analisa statistik terhadap variabel pengamatan untuk komponen pertumbuhan tanaman menunjukkan bahwa perbandingan antara Genotipe dan varietas berbeda nyata terhadap 2 (dua) parameter pengamatan yaitu tinggi tanaman dan jumlah daun.Tinggi tanaman tertinggi terdapat pada perlakuan cekaman sedang pada genotipe G-8 $(251,57 \mathrm{~cm})$ yang berbeda nyata lebih tinggi daripada varietas Bima 7 dan Gumarang.Sedangkan 8 genotipe untuk parameter jumlah daun tidak berbeda nyata dengan varietas bima 7 dan gumarang. Sifat tanaman yang diinginkan yaitu tidak terlalu tinggi dan memiliki batang yang kuat untuk mengurangi kerabahan yang akan berpengaruh terhadap produksi. Menurut Paliwal R.Let al. (2011) penampilan varietas jagung yang baik adalah tanamannya pendektetapikekar tahan terhadap kerebahan.Perbedaan tinggi tanaman dapat disebabkan karena perbedaan faktorgenetik antara varietas (Himawan dan Supriyanto, 2003).Pada umumnya sifattanaman yang diinginkan adalah tanaman yang berbatang pendek. Tanamanyang tidak terlalu tinggi dengan batang yang kuat dan pertumbuhan yang sehatdiharapkan dapat mengurangi resiko kerebahan yang dapat menurunkan hasil.Tanaman yang tidak terlalu tinggi juga memudahkan petani dalam melakukanpemeliharaan.Ketersediaan unsur hara yang cukup untuk pertumbuhan dan perkembangantanaman maka akan mendukung laju fotosintesis yang cepat, dengan fotosintesisyang sempurna, maka pada proses pembentukkan karbohidrat, lamak dan proteindapat berjalan dengan sempurna pula, sehingga akan diperoleh hasil yangmaksimal. Hal ini sesuai dengan pendapat Gardner et al., (1991) efesiensi fotosintesis terjadi bila luas daun lebih lebar, sehingga produk fotosintesis menjadi lebih optimal.

\section{Komponen Agronomi Tanaman}

Berdasarkan hasil analisis statistik terhadap variabel pengamtan untuk komponen produksi tanaman menunjukkan bahwa antara genotipe dan varietas memberikan pengaruh nyata terhadap 6 parameter pengamatan yaitu diameter tongkol, skoring penutup kelobot, bobot tongkol, panjang tongkol, bobot 1000 biji, kadar air biji, dan hasil per hektar (ton/ha) sedangkan diameter tongkol tidak berbeda nyata dengan varietas bima 7 dan gumarang. Berdasarkan data komponen produksi tanaman yang dominan menunjukkan pengaruh sangat nyata maka hal ini dapat diduga disebabkan oleh pemberian air sangat mempengaruhi proses produksi tanaman. Hal ini dapat terjadi karena pada saat proses fotosintesis, air sangat dibutuhkan untuk metabolisme sel, pembentukan bahan dan energi untuk masuk pada fase reproduksi pembentukan bunga dan pengisian biji sehinggga akan berpengaruh terhadap bobot tongkol dan hasil per hektar (ha/ton).Noggle dan Frizt (1983), menjelaskan bahwa fungsi air bagi tanaman yaitu :(1) sebagai senyawa utama pembentuk protoplasma, (2) sebagai pelarut bagi masuknya mineral-mineral dari larutan tanah ketanaman dan sebagai pelarut mineral nutrisi yang akan di angkut dari suatu bagian sel ke bagian sel ke bagian sel yang lain, (3) sebagai media terjadinya reaksi)reaksi metabolik, (4) menjaga turgiditas sel dan berperan sebagai tenaga mekanik pembesaran sel. Dari peran tersebut, maka konsekuensi langsung atau tidak langsung bila air tidak cukup tersedia akan mempengaruhi semua proses metabolik tanaman, sehingga menurunkan pertumbuhan dan produksi tanaman.Faktor lingkungan juga memberikan pengaruh terhadap umur panen, tanaman jagung dengan lingkungan yang mengalami cekaman air (Water stress), akan mengalami percepatan dalam umur panen. Menurut 
Adriani $d k k$., (2015), faktor lingkungan berkonstribusi nyata terhadap penampilan hibrida silang puncak untuk karakter umur panen, panjang tongkol dan bobot 1.000 biji.

\section{Kesimpulan}

Kesimpulan yang bisa diambil dari penlitian ini yaitu Genotipe G-1, G-3, G-6, G-7 dan G-8 mempunyai penampilan tanaman yang tertinggi dan terpanjang, pada kondisi optimal maupun tercekam kekeringan.Genotipe G-6, G-7 dan G-8 mempunyai bobot tongkol terberat, dan produksi tertinggi yaitu \pm 7 ton/ha pada kondisi optimal dan \pm 5 ton/ha pada kondisi tercekam kekeringan.

\section{Daftar Pustaka}

Abdurachman, A., A. Dariah, dan A. Mulyani. 2008. Strategi dan teknologi pengelolaan lahan kering mendukung pengadaan pangan nasional. Jurnal Litbang Pertanian 27(2) : 44.

Adriani A., M Azrai, W. B. Suwarno, S.H. Sutjahjo. 2015. Pendugaan Keragaman Genetik dan Heritabilitas Jagung Hibrida Silang Puncak pada Perlakuan Cekaman Kekeringan. Informatika Pertanian, Vol. 24 No. 1, Juni 2015 : 91 - 100.

Agustina K., Sopandie D., Trikoesoemaningtyas dan Wirnas D., 2010. Uji Adaptasi Sorgum pada Lahan Masam Terhadap Toksisitas Aluminium dan Defisiensi Fosfor. Dalam : Prosiding Seminar Nasional Serealia, Maros, 27-28 Juli 2010. Pusat penelitian dan Pengembangan Pertanian. P. 55-64.

Allard, R.W. 1960. Principles of Plant Breeding.John Wiley and Sons, Inc. New York. London. 485 p.

Efendi R, Suwardi, Isnaini M. 2009. Metode dan penentuan karakter seleksigenotipe jagung terhadap cekaman kekeringan pada fase awal vegetatif. Didalam: Prosiding Pekan Serealia Nasional 2010. Maros (ID) : BalaiPenelitian Tanaman Serealia.

Himawan, I. dan B. Supriyanto. 2003. Uji 3 varietas dan dosis pupuk NPK

mutiara terhadap pertumbuhan dan hasil kedelai (Glycine max L.). JurnalBudidaya Pertanian. Vol. 9(2):67-73.

Kementrian Pertanian. 2012. Teknologi Tanaman Pangan Menghadapi Perubahan Iklim, Badan Penelitian dan Pengembangan Pertanian Pusat Penelitian dan Pengembangan Tanaman Pangan. Varietas Jagung Toleran Kekeringan, Umur Genjah, Toleran Genangan, Tahan Hama dan Penyakit.

Noggle GR, GJ Pritz. 1983. Introducttory Plant Physiology.Prentice hall, inc. Egglewood Cliffs. New Jersey 627p.

Paliwal, R.L. 2011.Hybrid maize breeding. In: Paliwal, R.L., G. Granados, H.R. Lafitte, and A.D Violic (eds), Tropical Miaze: Improvement And Production. FAO, Rome, Italy.
Sopandie D. 2006.Perspektif Fisiologi dalam Pengembangan Tanaman Pangan di Lahan Marginal.Orasi Ilmiah Guru Besar Tetap Fisiologi Tanaman. Fakultas Pertanian, Institute Pertanian Bogor. 16 September 2006.

Van Der Have, J. 1979. Plant Breeding Perspectives. Centre for Agricultural Publ, and Documentation. Wageningen.Nedherland. 